Studia nad Autorytaryzmem i Totalitaryzmem 41, nr 4 Wrocław 2019

DOI: $10.19195 / 2300-7249.41 .4 .7$

\author{
ŁUKASZ ŚWIĘCICKI
}

ORCID: 0000-0001-6346-2825

Uniwersytet Przyrodniczo-Humanistyczny w Siedlcach

\title{
Carl Schmitt w polskich interpretacjach politologicznych (1984-2007)
}

\section{Wprowadzenie}

Carl Schmitt w ostatnich latach zyskał wiele na popularności w Polsce ${ }^{1}$. Łatwo można ulec złudzeniu, że w przeszłości był to w naszym kraju myśliciel mało znany, i próbować wyważać dawno otwarte drzwi interpretacyjne. Tymczasem nawet pobieżna kwerenda biblioteczna pokazałaby, że o Schmitcie pisano

${ }^{1}$ Dowodem tego niech będą nowe tłumaczenia dzieł Niemca, których w omawianym w artykule okresie nie było: Nauka o konstytucji, przeł. M. Kurkowska, R. Marszałek, Warszawa 2013; Teologia polityczna 2: legenda o wykluczeniu wszelkiej politycznej teologii, przeł. B. Baran, Warszawa 2014; Legalność i prawomocność, przeł. B. Baran, Warszawa 2015; Dyktatura: od źródet nowożytnej idei suwerenności do proletariackiej walki klas, przeł. K. Wudarska, Warszawa 2016; Teoria partyzanta: uwagi na marginesie „Pojęcia polityczności”, przeł. B. Cymbrowski, Warszawa 2016; O trzech rodzajach myślenia w nauce prawa, [w:] J. Zajadło, Schmitt, Sopot 2016; Nomos ziemi w prawie międzynarodowym ius publicum Europaeum, przeł. K. Wudarska, Warszawa 2019. Do tego spisu należy doliczyć jeszcze wznowienie (poszerzonego o jeden tekst) zbioru Teologia polityczna i inne pisma, przeł. M.A. Cichocki, Warszawa 2012 (wyd. 1 - 2000) oraz pomniejsze przekłady artykułów i fragmenty artykułów i książek (nieobecne w omawianym okresie): (1) Führer jest obrońca prawa, przeł. Piotr Graczyk; Etyka państwowa i państwo pluralistyczne, przeł. A. Serafin; Nowy nomos Ziemi, przeł. P. Wojciechowski; Trzy możliwości chrześcijańskiego obrazu historii, przeł. J. Ostrowski (wszystkie w „Kronos” 2010, nr 2); (2) Ex captivitate salus, przeł. A. i A. Klubowie; Ląd i morze, przeł. A. Lipszyc; Rozmowa z Eduardem Sprangerem, przeł. A. Żychliński; Rozmowa o władzy i dostęie do posiadającego władzę, przeł. A. Żychliński (wszystkie w „Przegląd Polityczny” 2014, nr 127-128); (3) Niemiecka nauka prawa w walce z duchem żydowskim. Wypowiedzi na konferencji niemieckich prawników w 1936 r., przeł. Ł. Święcicki, „Pro Fide Rege et Lege" 2014-2015, nr 1; (4) Strażnik konstytucji, przeł. A. Górnisiewicz; Absolutyzm, przeł. A. Górnisiewicz; Mieszczańskie państwo prawa. Weimarska demokracja konstytucyjna, przeł. Ł. Musiał; Dyktatura, przeł. K. Wudarska (wszystkie w „Przegląd Polityczny” 2016, nr 138); (5) Dodatki do „Pojęcia polityczności”, przeł. Ł. Święcicki, „Pro Fide Rege et Lege” 2017, nr 1-2. Wcześniejszą bibliografię thumaczeń zawiera: Polskojęzyczna bibliografia Carla Schmitta (do 2012 r.), oprac. Ł. Święcicki, „Pro Fide Rege et Lege” 2014-2015, nr 1.

Studia nad Autorytaryzmem i Totalitaryzmem 41, nr 4, 2019

(C) for this edition by CNS 
i w latach dziewięćdziesiątych minionego wieku, i w czasach PRL, i przed II wojną światową ${ }^{2}$. Wprawdzie dorobek polskiej recepcji naukowej nie jest tak duży jak w innych krajach, ale jest wystarczający, aby zasłużyć na jego przybliżenie ${ }^{3}$. Wiele opracowań dotyczących Schmitta (we wszystkich tych okresach) ukazało się w czasopismach mniej lub trudniej dostępnych, a książki (poza jednym wyjątkiem) nie były jak dotąd wznawiane. Wzorem zachodniej ,schmittologii” warto przybliżyć współczesnym czytelnikom historyczne ustalenia, zwłaszcza że opracowania tytułowego zagadnienia dotąd nie było. Studia recepcyjne pozwalają ocenić dotychczasowy stan badań, mogą przyczynić się do budowy świadomości badawczej kolejnych pokoleń interpretatorów, a także stanowić punkt wyjścia do dociekań na temat ewolucji poszczególnych stanowisk w ramach historii danego nurtu badawczego, ale i całej dyscypliny (mianowicie znaczenia problemu szczegółowego).

W niniejszym artykule przedstawiona zostanie politologiczna część polskiej recepcji myśli niemieckiego prawnika, jako że część prawnicza i filozoficzna została omówiona w innym miejscu ${ }^{4}$. Podział na prawniczą, filozoficzną i politologiczną recepcję Schmitta w Polsce, choć umowny, jest w pełni uzasadniony. Wynika on $\mathrm{z}$ ustaleń poczynionych $\mathrm{w}$ trakcie kwerendy polskich opracowań naukowych poświęconych myślicielowi. Kryterium zaszeregowania poszczególnych interpretacji był profil naukowy badacza, który — jak należy zakładać — rzutuje na jego sposób postrzegania danego problemu. Biorąc pod uwagę kilkadziesiąt lat obecności myśli niemieckiego prawnika w polskiej literaturze naukowej, daje się zauważyć, że Schmitt do lat osiemdziesiątych XX wieku interesował przede wszystkim prawników, zwłaszcza tych zajmujących się doktrynami polityczno-prawnymi. W późniejszym okresie myśl jego staje się przedmiotem badań głównie przedstawicieli nauki o polityce, jak gdyby prawnicy stracili zainteresowanie

2 Por. Ł. Święcicki, Carl Schmitt w polskich interpretacjach prawniczych (1928-2008), „Studia nad Autorytaryzmem i Totalitaryzmem” 36, 2014, nr 4, s. 101-131.

${ }^{3} \mathrm{Na}$ temat recepcji Carla Schmitta w innych państwach zob. m.in. A. de Benoist, Carl Schmitt: Internationale Bibliographie der Primär- und Sekundärliteratur, Graz 2010; zob. też stale aktualizowaną wielojęzyczną bibliografię dzieł Schmitta i prac na jego temat: http://www.carl-schmitt.de/neueste_veroeffentlichungen.php (dostęp: 1.08.2019). Warto nadmienić, że przez ,polską" recepcję Schmitta rozumiem opracowania naukowe wydane w języku polskim, z wyjątkiem tych, które są jedynie translacjami artykułów i rozdziałów autorów zagranicznych. Takie rozróżnienie jest standardowo przyjęte w zagranicznych studiach nad recepcją myśli Schmitta. Por. M. Baldus, Carl Schmitt im Hexagon: Zur Schmitt-Rezeption in Frankreich, „Der Staat” 26, 1987, nr 4, s. 566-586; V. Chacon, Die Rezeption Carl Schmitts in Brasilien, „Schmittiana. Beiträge zu Leben und Werk Carl Schmitts", t. 5, Berlin 1996, s. 305-313 (zwł. 305-308). Takie rozwiązanie (podział na autorów polskich i zagranicznych tłumaczonych na język polski) przyjęli w polskiej sekcji internetowej bibliografii Schmitta Marek Cichocki i Tomasz Krawczyk: http://www.carl-schmitt.de/ sec_CS_poland.pdf (dostęp: 1.08.2019).

4 Ł. Święcicki, Carl Schmitt w polskich interpretacjach...; idem, Nihilista czy fideista? O polskim sporze wokót Carla Schmitta, „Pro Fide Rege et Lege” 2017, nr 1-2, s. 299-315; idem, O recepcji Carla Schmitta w Polsce, „Pro Fide Rege et Lege” 2017, nr 1-2, s. 234-247. 
i przestali wieść prym w tym względzie. Z kolei w XXI wieku zauważalnie wzrasta liczba publikacji poświęconych Schmittowi autorstwa filozofów (vide środowisko czasopisma „Kronos” oraz „Krytyka Polityczna”). Co oczywiste, prawników, politologów i filozofów, nawet jeśli zajmują się tymi samymi dziełami Schmitta, interesują różne problemy, inaczej są też one postrzegane.

Na uwagę zasługuje to, że badania nad Schmittem przed 1989 rokiem znajdowały się mniej lub bardziej pod wpływem normatywnego i ideologicznego wartościowania, nawet jeśli była to jedynie lip service wobec autorytarnego systemu. Zajmowanie się Schmittem, „koronnym jurystą” Trzeciej Rzeszy w państwie znajdującym się w orbicie wpływów ZSRR, z obowiązującą jedyną właściwą ideologią, ze stale rozbudzanym - na podstawie pamięci nie tak dawnego okrucieństwa czasów wojny - antyniemieckim resentymentem, nie należało z pewnością do najłatwiejszych. Dopiero przemiany ustrojowe w pełni otworzyły możliwość obiektywnego, niewartościującego spojrzenia na dorobek Niemca. Być może jest to także pokłosie zmian w ocenie myśli i osoby Schmitta, które zaszły na Zachodzie - za sprawą wpływowych interpretacji w duchu nowej lewicy koncepcje autora Teologii politycznej zaczęto postrzegać bez moralnego potępienia ${ }^{5}$.

W ramach opisu i oceny politologicznej recepcji Schmitta wybrano jedynie te publikacje, które można uznać za mniej lub bardziej całościowe opracowania wprowadzające myśl „koronnego jurysty” na grunt nauki o polityce. Pominięto zatem pozycje jedynie inspirowane Schmittem i jego kategoriami teoretycznymi. Po pierwsze, nie sposób bowiem w jednym artykule omówić nie tylko wszystkich, ale nawet wybranych, najważniejszych polskich interpretacji Niemca, nie narażając się na zarzut arbitralności dokonanego wyboru ${ }^{6}$. Po drugie, jako kryterium wyboru autorów przyjęto znaczenie danego badacza dla recepcji Schmitta. W tym kryterium uwzględniono przede wszystkim fakt autorstwa monografii poświęconej autorowi Pojęcia polityczności. Wyjątek od tej reguły stanowią dwaj badacze - w wypadku obu Schmitt odgrywa ogromną rolę w ich najważniejszych monografiach, są też autorami licznych artykułów poświęconych Niemcowi lub thumaczami jego fundamentalnych dzieł na polski. Wszystkich wybranych tu autorów można, co nie bez znaczenia, zaliczyć do specjalności „historia myśli politycznej".

Zakres czasowy artykułu tworzą, z jednej strony, wczesne studia z teorii polityki Franciszka Ryszki, z drugiej — ostatnie efekty badań nad konserwatyzmem

5 Por. I. Mauss, Bürgerliche Rechtstheorie und Faschismus. Zur sozialen Funktion und aktuellen Wirkung der Theorie Carl Schmitts, München 1980; Ch. Mouffe, The Return of the Political, London-New York 1993. Warto również pamiętać o trudnym do przecenienia wkładzie w popularyzację myśli Schmitta w świecie anglojęzycznym, jaki stał się udziałem wydawanego w USA lewicowego czasopisma „Telos”.

6 Por. A. Wielomski, Interpretacje Carla Schmitta na świecie i w Polsce, „Studia nad Faszyzmem i Zbrodniami Hitlerowskimi” 33, 2011, s. 415-431. 
Schmitta przed „wysypem” nowych thumaczeń ${ }^{7}$ oraz przed ważną dla polskiej recepcji myśli Niemca pracą Adama Wielomskiego ${ }^{8}$. Początek wyznaczony został nie tyle ze względu na ideologiczne wyzwolenie nauki o polityce, ile z racji tego, że w okresie PRL polska recepcja była zdominowana przez prawników, co zasadniczej zmianie uległo dopiero w okresie transformacji ustrojowej ${ }^{9}$.

\section{Schmitt jako teoretyk polityki/polityczności}

W okresie Polski Ludowej myśl Carla Schmitta była obiektem zainteresowania głównie prawników, co narzucało prawniczą perspektywę interpretacji. Wraz z rozwojem nauki o polityce jako samodzielnej dyscypliny stopniowo odkrywano politologiczne znaczenie idei niemieckiego prawnika. Poglądy dotyczące państwa, konstytucji, polityki, ujmowane nie w kategoriach filozoficzno-prawnych, lecz typowych dla historii myśli politycznej, zaczęto rozpatrywać w wymiarze politycznym; atrakcyjność i świeżość refleksji Schmitta okazała się przydatna w teorii polityki. Z interpretacją teoretyczno-polityczną związane jest postrzeganie Schmitta jako konserwatysty. Samo dostrzeżenie konserwatyzmu Niemca nie jest oryginalne i było obecne także w niektórych pracach interpretacji prawniczej, jednak to w nurcie politologicznym jego konserwatyzm został ujęty jako problem naukowy.

Interpretacja politologiczna, co istotne, zrywa $\mathrm{z}$ moralnym potępieniem Schmitta typowym dla studiów prawniczych z lat wcześniejszych. Niemiecki prawnik jest postrzegany już nie tylko jako teoretyk prawa, ale jako teoretyk polityki. Kwestia współpracy z reżimem narodowosocjalistycznym przestaje być wyznacznikiem oceny wartości jego idei. Jak zwraca uwagę Ryszard Skarzyński

7 Dla najnowszej recepcji Schmitta w Polsce przełomowe były lata 2007-2010, kiedy po długiej przerwie w różnych czasopismach („Krytyka Polityczna”, „Kronos”, „Przegląd Polityczny”) ukazały się liczne przekłady dzieł Schmitta. W 2008 roku opublikowano także przekład książki Lewiatan w teorii państwa Tomasza Hobbesa (przeł. M. Falkowski). Szczegółowy wykaz tłumaczeń zob. Ł. Święcicki, O recepcji Carla Schmitta..., s. 238.

8 Zob. A. Wielomski, Konserwatyzm między Atenami a Jerozolima: szkice post-awerroistyczne, Warszawa 2009. Pracę Wielomskiego uważam za przełomową dla recepcji Schmitta w tym sensie, że wprowadza ona na grunt polski, za Heinrichem Meierem (Die Lehre Carl Schmitts. Vier Kapital zur Unterscheidung Politischer Theologie und Politischer Philosophie, Stuttgart-Weimar 2009, wyd. 1 - 1994), fideistyczne rozumienie teologii politycznej Schmitta. Wcześniejsze studia, także Wielomskiego, koncentrują się na rozumieniu teologii politycznej jako tak zwanego teorematu sekularyzacyjnego. Teologia polityczna w ujęciu Meiera i Wielomskiego jest źródłem i istotą myśli polityczno-prawnej Schmitta. Ten sposób odczytania jego myśli byłby niemożliwy bez uwzględnienia wydanych pośmiertnie dzienników Schmitta zatytułowanych Glossarium. Na temat interpretacji Meiera w kontekście polskiej recepcji zob. Ł. Święcicki, Nihilista czy fideista?...; por. F. Ryszka, Carl Schmitt w nauce prawa i polityki XX w. Twórca i jego dzieło. Szkic do portretu $i$ wybrane watki teorii, „Studia nad Faszyzmem i Zbrodniami Hitlerowskimi” 19, 1996.

9 Por. Ł. Święcicki, Carl Schmitt w polskich interpretacjach... 
(pisząc o komentatorach zagranicznych sprzed kilkudziesięciu lat), zagorzali antagoniści Schmitta, niejednokrotnie dokonując oceny moralnej autora Pojęcia polityczności, lekceważyli przy tym jego dorobek naukowy ${ }^{10}$. Tym samym warunkiem koniecznym studiów dotyczących tego myśliciela politycznego okazuje się zachowanie postawy rozumiejącej i obiektywizującej, ku czemu dążą przedstawiciele politologicznej interpretacji Niemca.

\section{1.}

Ujmowanie Schmitta jako teoretyka polityki było charakterystyczne zwłaszcza dla prac z lat dziewięćdziesiątych XX wieku, ale geneza tej interpretacji sięga jeszcze dekady poprzedniej i wiąże się z Franciszkiem Ryszką. Wydana w 1984 roku książka Nauka o polityce. Rozważania metodologiczne była przede wszystkim podręcznikiem akademickim, aczkolwiek przedstawiała również rozwiniętą później przez badacza interpretację myśli Schmitta, pozbawioną dominanty prawniczej ${ }^{11}$.

Ryszka wyróżnia dwa obecne $\mathrm{w}$ historii rozumienia polityki ${ }^{12}$. Pierwsze, optymistyczne, pojmuje politykę jako sztukę najlepszego, to jest uwzględniającego interesy innych, wyboru między różnymi możliwościami ${ }^{13}$. Z tendencją tą wiążą się osiągnięcia renesansu, oświecenia, koncepcje Jeana-Jacquesa Rousseau i Johanna Gottlieba Fichtego. Drugi nurt, pesymistyczny, „dostrzega przede wszystkim konflikt". Wychodząc z innych założeń antropologicznych, uznaje, że ważny jest konflikt, a zwłaszcza jego rozstrzygnięcie, „decyzja nadrzędna”14. Do takiego pojmowania polityki Ryszka przyporządkowuje przedstawicieli katolickiej doktryny kontrrewolucyjnej, romantyków niemieckich Adama Müllera, Franza Xavera Baadera, ultramontanów Josepha de Maistre'a, Bonalda oraz Jaime Balmes'a i Juana Donoso Cortèsa ${ }^{15}$.

Streszczenie poglądów ostatniego okazuje się wprowadzeniem do kluczowego dla myśli Carla Schmitta pojęcia teologii politycznej. Ryszka, zgadzając się z Niemcem, odrzuca optymistyczno-anarchistyczny pogląd o naturze człowieka, twierdząc,

10 Por. uwagę Skarzyńskiego z jego Przedmowy do wydania drugiego, [w:] idem, Od chaosu do tadu. Carl Schmitt i problem tego, co polityczne, Warszawa 2012, s. 21 i przyp. 21 na tej samej stronie.

11 F. Ryszka, Nauka o polityce. Rozważania metodologiczne, Warszawa 1984. Książką tą Ryszka potwierdził duży wpływ, jaki miała na niego myśl Schmitta, wykraczający poza uznanie w niemieckim myślicielu współczesnego klasyka. Warto w tym miejscu odnotować, że Ryszka o Schmitcie pisał również w innych swych pracach, zwłaszcza Państwie stanu wyjątkowego (które należy zaliczyć do interpretacji prawniczych), lecz także w: idem, Polityka i wojna. Świadomość potoczna a teorie XX wieku, Warszawa 1975 . Ta ostatnia historyczna praca antycypuje rozważania politologa z 1984 roku.

12 Por. J. Baszkiewicz, F. Ryszka, Historia doktryn politycznych i prawnych, Warszawa 1973.

13 F. Ryszka, Nauka o polityce..., s. 10.

14 Ibidem.

15 Ibidem, s. 11. 
że nawet przyjąwszy go, musi on nas zaprowadzić do wniosków podobnych jak u filozofów kontrrewolucyjnych - konieczna jest surowa decyzja, rozstrzygająca i ostateczna ${ }^{16}$. Przedstawiając Schmitta, określa go mianem ,pisarza na wskroś konserwatywnego" i zwolennika Machiavellego i Hobbesa. Przypomina jego akces do hitleryzmu, ale zastrzega, że „nie uznawał obłąkanych tez hitlerowskich”, a opinia

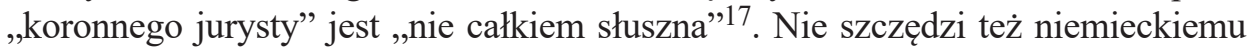
prawnikowi pochwał: „umysł wyjątkowo przenikliwy i bystry, posiadający rzadką zdolność do syntezy i budowania teorii zwartych i sugestywnych"18.

Dla wykładu Ryszki o polityce najważniejszy jest oczywiście tekst Pojęcia polityczności, w którym Schmitt wyłożył swoją teorię polityki. Niemiecki myśliciel, jego zdaniem, przyjmuje dialektykę politycznych działań odmienną od Heglowskiej dialektyki prawa, albowiem granice polityki określa podstawowe przeciwieństwo, które nie ma racjonalnego sensu. Według Ryszki Schmitt jest „krańcowym relatywistą", ponieważ polityki w tym rozumieniu nie można uszeregować w ciąg logiczno-historyczny, w którym jedno wynika z drugiego ${ }^{19}$. Jest tylko przeciwieństwo, które określa politykę.

Ryszka przedstawia główne tezy Schmitta dotyczące rozróżnień FreundFeind, staatlich-politisch stanowiące rozwinięcie uwag początkowych o naturze polityki ${ }^{20}$. Ich uzupełnieniem jest komentarz do Teorii partyzanta. Schmitt w tym dziele okazał się bowiem według Ryszki „równie bystrym obserwatorem” procesów dekolonizacyjnych, rewolucji i wojen narodowowyzwoleńczych oraz ,pilnym czytelnikiem” dzieł Mao Zedonga, Ernesto Guevary i klasyków marksizmu ${ }^{21}$.

Można powiedzieć, że Nauka o polityce Ryszki (z wykształcenia prawnika) wprowadziła Schmitta na terytorium rozważań politologicznych; stał się on równoprawnym teoretykiem, choć może jeszcze nie klasykiem, nauki o polityce co inni wielcy ${ }^{22}$.

Zasadniczy wkład w rozwój interpretacji Schmitta jako teoretyka polityki wniósł za sprawą swojej pierwszej polskiej monografii o tym myślicielu Ryszard Skarzyński. Poprzedziły ją jednak artykuły poświęcone myśli Niemca. Na wstępie należy zauważyć, że niemal od początku teoria Schmitta służyła temu badaczowi

16 Ibidem, s. 13-14.

17 Ibidem, s. 154.

18 Ibidem.

19 Ibidem.

20 Ibidem, s. 155.

21 Ibidem, s. 156.

22 Do uwag Schmitta o polityce Ryszka powrócił w stricte politologicznej książeczce o znamiennym tytule O pojęciu polityki z 1992 roku. Uznał w niej Carla Schmitta za jednego z trzech uczonych (obok Maxa Webera i Helmutha Plessnera), którzy dla nowoczesnej nauki o polityce odegrali „nieocenioną rolę”; zob. F. Ryszka, O pojęciu polityki, Warszawa 1992, s. 50. 
do postawienia własnych propozycji i tez ${ }^{23}$. Dobitnym przykładem niech będzie (nieudana) próba wprowadzenia do polskiego dyskursu naukowego tłumaczenia das Politische jako „tego, co polityczne”.

Jedno z wcześniejszych omówień myśli Carla Schmitta Skarzyński zaprezentował w wydanym w 1991 roku artykule Teoria polityki w okresie przełomu: Carl Schmitt i problem tego, co polityczne $e^{24}$. Teoria Schmitta jest dla niego wynikiem „kryzysu społeczeństwa europejskiego” i ,kryzysu intelektualnego”, wobec którego pojawiły się próby „rekonstrukcji” między innymi konserwatyzmu, którego przedstawicielem jest właśnie ten niemiecki myśliciel ${ }^{25}$. Schmitt wpisując się w tradycję kontrrewolucyjną, głosi przekonanie o upadku „przewodnich idei społeczeństwa”, na który to upadek jego teoria ma stanowić reakcję, „,próbę przeciwstawienia się," 26 . Decyzjonizm i teoria tego, co polityczne, są więc ,produktem konstatacji o konieczności odrodzenia filozofii polityki" ${ }^{27}$. Pojęcie tego, co polityczne, jest również „produktem kryzysu tradycyjnej niemieckiej Staatslehre”28.

Zdaniem Skarzyńskiego o kryzysowym charakterze myśli Schmitta świadczy sekularyzacja jego przekonań. Schmitt odrzucił bowiem charakteryzujący go początkowo normatywizm, a późniejsze jego decyzjonistyczne dzieła pozbawione są ,podstaw metafizycznych”; niemiecki teoretyk, jak pisze białostocki politolog, ,zbyt dobrze zdawał sobie sprawę ze zmian dokonujących się na świecie i w świadomości społecznej, aby odczuwać potrzebę poszukiwania absolutu" 29 .

Pogląd Schmitta na naturę ludzką sprowadza się do tezy, że każda poprzedzająca teorię polityki koncepcja antropologiczna jest odzwierciedleniem interesów politycznych i „deklaracji ideologicznej”, którym służy za uzasadnienie ${ }^{30}$. Dlatego poszczególne dziedziny ludzkiej aktywności zakładają inne wizje natury człowieka. Inne jej wyobrażenie ma pedagog czy teolog, a inne teoretyk polityki, który pojmuje ją jako realny konflikt ${ }^{31}$.

23 Już w 1990 roku w artykule o nieprzypadkowym tytule Wróg i sojusznik. Studium struktury myśli politycznej Skarzyński nie zajmuje się samym Schmittem, lecz korzysta z jego aparatu pojęciowego, aby wyjaśnić problem struktury myśli politycznej. Jego zdaniem „destabilizacja społeczeństwa" prowadzi do ścierania się dwóch antagonistycznych obozów — rewolucjonistów i kontrrewolucjonistów. Intelektualiści nie są potęgą narzucającą poglądy masom, chociaż są „twórcami” i ,producentami” wiedzy, zwłaszcza idei politycznych. Ich celem jest podtrzymanie lub dezintegracja światów ideowych. Przykładem takiego intelektualisty jest właśnie Schmitt. Zob. R. Skarzyński, Wróg i sojusznik. Studium struktury myśli politycznej, „Studia Nauk Politycznych” 1990, nr 1-3, s. $59,60,63-64$.

${ }^{24}$ R. Skarzyński, Teoria polityki w okresie przełomu: Carl Schmitt i problem tego, co polityczne, „Państwo i Kultura Polityczna” 1991, nr 3.

${ }^{25}$ Ibidem, s. 16-17.

26 Ibidem, s. 17.

27 Ibidem, s. 27.

28 Ibidem, s. 31-32.

29 Ibidem, s. 18.

30 Ibidem, s. 20-21.

31 Ibidem, s. 21.

Studia nad Autorytaryzmem i Totalitaryzmem 41, nr 4, 2019

(C) for this edition by CNS 
Warto nadmienić, że Skarzyński jako pierwszy badacz w Polsce — za ustaleniami Heinricha Meiera — zwrócił uwagę na różnice w kolejnych wydaniach Pojęcia polityczności, z których podstawową jest różnica podmiotu polityki państwo w wydaniu pierwszym, a różne antagonistyczne grupy w stanie wojny domowej $\mathrm{w}$ drugim $^{32}$. Dokonawszy egzegezy i porównania następujących po sobie wersji tekstu, badacz naświetla również kryteria wyróżnienia tego, co polityczne, i ich stosunek do innych dziedzin życia (moralności, estetyki, ekonomii), a także inne drobniejsze zmiany w tekście ${ }^{33}$. Jego zdaniem Schmitt zrezygnował z rozważań nad „obszarem tego, co polityczne” i skoncentrował się na analizie kryteriów das Politische ${ }^{34}$. W pierwszym wydaniu Pojęcia polityczności Skarzyński zauważa to, na co już Leo Strauss w 1932 roku zwrócił uwagę Schmittowi w recenzji tejże pracy, czyli problem samodzielności dziedziny tego, co polityczne, aczkolwiek w przeciwieństwie do Straussa polski badacz nie wypowiada tej kwestii explicite.

Znaczenie Schmitta we współczesnej teorii polityki wynika według Skarzyńskiego z ukazania przez niego znaczenia refleksji nad „tym, co polityczne”. Wizje „tego, co polityczne” nie są obojętne na ideologiczne wpływy, więc i teoria Schmitta nie jest od nich wolna, twierdzi Skarzyński, ale samo kryterium polityczności zdaje się obiektywne. Teoria ta jest realistyczna, ponieważ ujmuje rzeczywistość taką, jaką ona jest, a nie według postulatów normatywnych twórcy, oddając tym samym sedno konfliktu między podmiotami polityki w jego egzystencjalnym wymiarze ${ }^{35}$. Skarzyński czyta zatem Schmitta w sposób nominalistyczny. Teoria Niemca ma dla niego charakter ściśle empiryczny, nie ma odniesień do fundamentalnej substancji, do której odwoływaliby się inni konserwatyści. Dla Skarzyńskiego Schmitt jest konserwatystą specyficznym, ponieważ tworzył teorię wolną od ugruntowania metafizycznego, niezawierającą odniesień do absolutu, różnił się od innych konserwatystów także spojrzeniem na społeczeństwo, a w kwestiach aksjologicznych nie był jak oni absolutystą ${ }^{36}$. Do problemu relacji myśli Schmitta do tradycji konserwatyzmu europejskiego Skarzyński odnosi się $\mathrm{w}$ innym ze swoich tekstów ${ }^{37}$. Białostocki politolog, postrzegając dzieła Schmitta jako próbę „rekonstrukcji konserwatyzmu” w okresie kryzysu społeczeństwa, poddaje krytyce jego konserwatyzm. Omawiając założenia decyzjonizmu, odnosi filozofię polityczną niemieckiego prawnika do rewolucyjnego konserwatyzmu i nazizmu oraz klasycznego i współczesnego konserwatyzmu.

32 Ibidem, s. 25.

33 Ibidem, s. 27-28.

34 Ibidem, s. 28-29.

35 Ibidem, s. 33.

36 Ibidem, s. 18, 20, 21, 30; por. R. Skarzyński, Carl Schmitt - ideolog i politolog, [w:] Carl Schmitt i współczesna myśl polityczna, red. R. Skarzyński, Warszawa 1996, s. 46.

37 R. Skarzyński, Carl Schmitt i współczesny konserwatyzm europejski, „Archiwum Historii Myśli Politycznej” 1991, nr 1. 
Konserwatyzm w pracy Skarzyńskiego ujęty jest w sposób socjologiczny, nieco nawet marksizujący (czynniki ekonomiczne, baza odgrywają prymarną rolę w jego interpretacji), jako zjawisko charakterystyczne dla czasów „,destabilizacji społeczeństwa", ponieważ stanowi on reakcję zagrożonych utratą swojej pozycji grup społecznych. Konserwatyzm Schmitta jest dwuczłonowy, tworzy go konserwatyzm postawy politycznej, wyrażający się w dostosowywaniu się do istniejącego aktualnie reżimu oraz „filozofia podstawowej sytuacji egzystencjalnej”, która jest pomocna $\mathrm{w}$ poznaniu istoty polityczności, lecz bezradna wobec potrzeby skonstruowania odpowiedzi na wyzwanie sytuacji egzystencjalnej ${ }^{38}$.

Schmitt był według Skarzyńskiego konserwatystą, ale w warstwie aksjologicznej jego konserwatyzm (jako ideologia) jest ułomny, ponieważ brakuje w nim systemu wartości mogącego stać się fundamentem ładu społecznego. Głównym zarzutem Skarzyńskiego wobec decyzjonizmu Schmitta jest, co zaskakujące, wskazanie braku realistycznego programu politycznego. Rozważania niemieckiego „rzecznika dyktatury” są jego zdaniem interesujące jako uwagi o sytuacji egzystencjalnej czy relacji między stanem natury a państwem, ale w istocie więcej w nich romantycznej tęsknoty za monarchią niż praktycznych odpowiedzi na pytania o model suwerena. Zarzut braku realizmu u Schmitta oznacza zatem dla Skarzyńskiego trudność w bezpośrednim zastosowaniu idei Niemca w nieprzystawalnym do jego ,ideologii” świecie. Jest to raczej nietypowa uwaga dla komentatorów Schmitta, którzy zazwyczaj podnoszą znaczną zdolność dostosowania jego myśli do poszczególnych ustrojów. Wynika to z tego, że Skarzyński chce w założeniu traktować myśl Niemca jako teorię, a nie ideologię, dlatego jej polityczne zastosowanie postrzega jako wyraz woli jej twórcy działającego przeciwko materii wytworzonych przez siebie narzędzi intelektualnych.

Widać to dobrze w kwestii oceny relacji Schmitta wobec nazizmu, w których Skarzyński odróżnia związek osoby i myśli z hitlerowskim reżimem. Jego zdaniem Schmitt jako człowiek skompromitował się podwójnie: ze względu na poparcie i członkostwo w NSDAP oraz uprawomocnianie i gloryfikację systemu w swoich tekstach. Ale czy przez to również skompromitowała się jego myśl? Jak zauważa Skarzyński, Schmitt był oczywiście krytykiem demokracji, parlamentaryzmu, proponował stworzenie dyktatury (,prawdziwej demokracji”), której ucieleśnieniem mógłby być Führer, ale przed dojściem do władzy nazistów niemiecki myśliciel nie był ich zwolennikiem ani też totalnym krytykiem Weimaru, a w miejsce ułomnej demokracji, zgodnie z wyłożonymi poglądami, postulował wprowadzenie dyktatury komisarycznej, czyli mniej radykalnej niż dyktatura suwerenna. Jak podkreśla politolog, jeszcze w lipcu 1932 roku, tuż przed wyborami, Schmitt wyrażał publiczną dezaprobatę wobec hitlerowców w artykule oskarżającym narodowy socjalizm o aktywizm, nieobliczalność i niezdolność stabilizacji państwa. Według Skarzyńskiego Schmitt jako konserwatysta konsekwentny

\footnotetext{
38 Ibidem, s. 53.
} 
zawsze stał po stronie państwa, przedkładając rzeczywistość nad ideały: „,[w] obawie przed zagrożeniem państwa wolał on reformować go w ramach właściwego mu porządku konstytucyjnego aniżeli narażać na wstrząsy związane z realizacją rozwiązań radykalnych"39. Postawa ta, niewynikająca z jego filozofii politycznej, lecz temperamentu politycznego, doprowadziła go do NSDAP ${ }^{40}$. Skarzyński zdaje się zatem oddzielać zasadniczy zrąb myśli Schmitta od jej praktycznego oddziaływania, uzależnionego od oportunistycznych skłonności charakteru Niemca.

Podkreślany przez Skarzyńskiego ogólnikowy charakter decyzjonizmu rozmywa związek między nim a nazizmem. Obojętne jest dla tego badacza, że może być zinterpretowany w sposób użyteczny dla Trzeciej Rzeszy, co czynił sam Schmitt, albowiem właściwe niemieckiemu juryście poglądy, wykrystalizowane zresztą przed 1933 rokiem, nie mogły przewidzieć niewyobrażalnych zbrodni niemieckich. Decyzjonizm zaś był efektem ,protestu przeciwko upadkowi monarchii”, a słabość tej filozofii politycznej potwierdziło odrzucenie Schmitta przez hitlerowski reżim ${ }^{41}$.

Kolejnym zarzutem Skarzyńskiego wobec konserwatyzmu Schmitta jest niepozostawanie w horyzoncie tradycyjnego europejskiego konserwatyzmu. Tworząc fundamenty decyzjonizmu, Schmitt korzystał z myśli kontrrewolucyjnej de Maistre'a i Donoso Cortèsa, ale w sposób selektywny wybierał potrzebne mu elementy. Nie określił również, typowej dla konserwatyzmu XIX wieku, własnej wizji ładu, naturalnego porządku. W to miejsce proponuje ideę suwerena instalującego ład mocą swojej decyzji, tym samym odrzucając typową dla klasyków konserwatyzmu ideę tradycji, która może jedynie ograniczać decyzję. Suweren, jako strażnik porządku, nie odkrywa porządku naturalnego, lecz tworzy porządek „prawdziwy”, który jest normalnym, właściwym ładem. Stworzony przez człowieka (suwerena) ład leży u podstaw idei autonomii rzeczywistości wobec ludzkiej woli. Jest to jednak, pisze Skarzyński, rzeczywistość wolna od ,jakiegokolwiek zakorzenienia w absolucie", a więc inna niż w tradycyjnym konserwatyzmie XIX wieku ${ }^{42}$.

Według Skarzyńskiego Schmitt radykalizuje poglądy de Maistre'a i Donoso Cortèsa, nie podejmując $\mathrm{w}$ ogóle problemu Boga rozumianego prowidencjalnie (Bóg ingerujący w życie ludzi) ${ }^{43}$. Podważa również fundamenty konserwatyzmu, uznając stan natury za realny, a suwerena za nieograniczonego jakimikolwiek wartościami. „Schmitt był bowiem przekonany — pisze Skarzyński — że metafizyka jest tylko wyrazem ducha danej epoki, tak jak oczywistość uprawomocnienia nie stanowi czegoś absolutnego, lecz wyłącznie odbicie zmieniającego się

\footnotetext{
39 Ibidem, s. 46; por. R. Skarzyński, Carl Schmitt - ideolog i politolog..., s. 42.

40 Ibidem, s. 55.

41 Ibidem, s. 42.

42 Ibidem, s. 47-48.

43 Ibidem, s. 48-50.
} 
systemu przekonań, gdyż każda epoka ma swoje pojęcia i wartości"44. Tym samym Bóg staje się w decyzjonizmie nieistotny, a jego miejsce zajmuje suweren jako nowy absolut. Doprowadzając to rozumowanie do końca, należy stwierdzić, że decyzjonizm jest koncepcją władzy będącej strażnikiem każdego ładu społecznego, o ile jest on stabilny i trwały.

Niewskazanie aksjologicznych uwarunkowań władzy w teorii Schmitta zbliża go do Hobbesa oraz nihilizmu, twierdzi Skarzyński ${ }^{45}$. Namiastką brakującego „podłoża metafizycznego" ma być teologia polityczna. Nie ma ona jednak odniesienia do absolutu, ponieważ uprawomocnienie jest zawsze wytworem danej epoki historycznej i tylko w niej jest obowiązujące. Zdaniem Skarzyńskiego Schmitt, bezsilny wobec procesów delegitymizacji i „rozpadu zespołów wartości leżących dotychczas u podłoża porządku społecznego", nawiązuje do Donoso Cortèsa, ponieważ w sytuacji upadku wartości możliwa jest tylko dyktatura. Skarzyński jest sceptyczny co do koncepcji teologii politycznej. Jego zdaniem także Teologia polityczna II nie zaproponowała żadnego systemu wartości. Schmitt, „zrywając z metafizyką [...], zerwał też z teologią polityczną"46. Tym samym odszedł od klasycznego konserwatyzmu europejskiego, a „teologiczna podbudowa zsekularyzowanych pojęć nowoczesnej nauki o państwie" nie powiodła się.

Obok wspomnianych zarzutów Skarzyński doszukuje się sprzeczności Schmittowskich koncepcji. Jego zdaniem idee Schmitta są efektem „dezintegracji świata ideowego konserwatyzmu [postrewolucyjnego - Ł.Ś.] [...], a nawet zmierzchu klasycznego paradygmatu konserwatyzmu wspartego takimi ideami, jak: tradycja, absolut i lokalna społeczność" ${ }^{47}$.

\section{3.}

Najważniejszą pracą Skarzyńskiego, a zarazem pierwszą monografią dotyczącą Schmitta jest jego książka z 1992 roku pod tytułem Od chaosu do ładu. Carl Schmitt i problem tego, co polityczne ${ }^{48}$. Osią refleksji nad filozofią polityczną decyzjonizmu Schmitta autor uczynił, podobnie jak Ryszka, tekst ,najgłośniejszego traktatu politologicznego XX w.", czyli Pojęcie polityczności ${ }^{49}$. Właściwie zamiast „tekst” należałoby powiedzieć „teksty”, ponieważ Skarzyński analizuje różnice między kolejnymi wydaniami tej pracy a znaczeniem, jakie z tych różnic wynika dla oceny teorii niemieckiego myśliciela (i powstałych interpretacji) oraz jego politycznej aktywności.

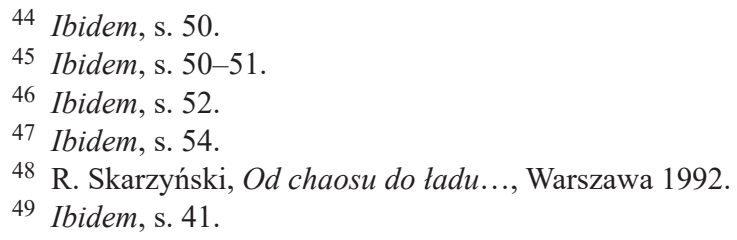


Zajmowanie się dorobkiem Schmitta jest niemożliwe, jak stwierdza Skarzyński, bez przyjęcia odpowiedniego stanowiska wobec jego postawy politycznej. Sprawa ta wzbudza wielkie emocje, a kwestią zasadniczą jest to, czy poglądy „nazywanego, zresztą całkowicie niesłusznie, koronnym jurystą” prawnika doprowadziły go do członkostwa w NSDAP. Zdaniem Skarzyńskiego tworzenie takiej zależności nie tłumaczy fenomenu Schmitta, dlatego że jego motywacje były niewyrafinowane; za postawą polityczną kryła się jedynie zdolność przystosowania się do każdej sytuacji i popierania każdego reżimu, albowiem „decyzjonizm [...] nadaje się nie tylko do legitymizacji dyktatury, ale również i demokracji konstytucyjnej" ${ }^{\prime 50}$.

Stworzonej przez siebie filozofii politycznej Schmitt użył „dla pozornej kariery politycznej", co najlepiej obrazuje przykład kolejnych edycji Der Begriff des Politischen, które uaktualniał, chcąc się dostosować do otaczającej go nowej rzeczywistości. Tak więc wśród wielu zmian w trzecim wydaniu z 1933 roku Schmitt między innymi usunął nazwiska ewidentnych wrogów narodowego socjalizmu (Diltheya, Plessnera, Lukacsa, Lenina), uprościł język, wyostrzył krytykę pluralizmu oraz dodał typowo nazistowskie określenia i zwroty ${ }^{51}$. Skarzyński dostrzega również zmiany w samej strukturze tekstu, czego przykładem jest przeredagowanie początkowego zdania (,pojęcie państwa zakłada pojęcie tego, co polityczne” na „właściwe rozróżnienie polityczne jest rozróżnieniem przyjaciela i wroga”), którym nieodłącznie powiązał politykę z wojną ${ }^{52}$. Politolog z Białegostoku zarzuca Schmittowi „fałszerstwo” i „manipulację”, do których dopuszczał się, pisząc o swoich wcześniejszych publikacjach jako praktycznie niezmienionych ${ }^{53}$.

Broniąc z kolei Schmitta przed krytykami, stwierdza, że jego wkład w intelektualne unicestwienie Republiki Weimarskiej nie był „tak jednoznaczny, jak może się wydawać”. Odróżniając jak najbliższe ideologom antydemokratycznej prawicy założenia decyzjonizmu od politycznych propozycji myśliciela, potwierdza tezę, iż był on na tyle lojalny wobec aktualnego reżimu, aby nie przekładać swoich wizji na uderzający w Republikę Weimarską program ${ }^{54}$.

Ważniejszym problemem interpretacyjnym jest dla Skarzyńskiego koncepcja państwa totalnego, którą Schmitt sformułował już w 1928 roku i rozwijał w latach następnych. Pojawiające się w jego tekstach pojęcie totaler Staat stało się przedmiotem ataków i dezinterpretacji (Herbert Marcuse, Waldemar Gurian), których celem było wykazanie „totalitarnego” charakteru jego myśli ${ }^{55}$. Tymczasem, jak pokazuje Skarzyński, Schmitt definiował totalność państwa inaczej, niż czynili to naziści. Co więcej, koncepcja ta ewoluowała w ciągu lat. W Verfassungslehre

\footnotetext{
50 Ibidem, s. 14.

51 Ibidem, s. 15-16.

52 Ibidem, s. 16-17.

53 Ibidem, s. 18-19.

54 Ibidem, s. 14.

55 Ibidem, s. 20.
} 
totalność państwa wynika z nieuznawania przez nie ,żadnej innej jednostki, posiadającej identyczne uprawnienia i swoistą formę publiczno-prawną" i odnosi się do prymatu relacji prawno-państwowych wyznaczanych przez prawo międzynarodowe, a nie stosunki wewnętrzne ${ }^{56}$. Z kolei w pracach Der Hüter der Verfassung i Der Begriff des Politischen, „państwo totalne zostało ukazane jako wytwór procesów wiodących do upadku odżegnującego się od interwencjonizmu państwa liberalnego i powstania państwa prawnego". Schmitt ukazuje jedynie proces przejmowania państwa przez masy, który eliminuje dotychczasową elitę kontrolującą instytucje państwa. Zdaniem Skarzyńskiego Schmitt nie jest więc „rzecznikiem tendencji wiodących do państwa totalnego”, lecz „krytykiem tych procesów”, ponieważ jako konserwatysta konsekwentny niechętny jest „polityzacji życia spolecznego" 57 .

Przyjmując za podstawę tekst Der Begriff des Politischen z 1932 roku, w którym Schmitt pisze o niemożliwym rozróżnieniu w sytuacji całkowitej polityzacji życia, typowej państwu totalnemu, między państwem a tym, co polityczne, Skarzyński stwierdza, że broniąc polityczności, niemiecki myśliciel musiał krytykować państwo totalne, ponieważ zaciera się w nim jej specyficzność. Schmitt występował przeciwko zarówno nadmiernej polityzacji, jak i nadmiernej depolityzacji, czyli przeciw liberalizmowi, opowiadając się za właściwym miejscem tego, co polityczne, w życiu społeczeństwa ${ }^{58}$.

Dokonując zmian w swoich tekstach w okresie nazistowskim Schmitt zanegował dotychczasowe wnioski związane z decyzjonizmem. Na tle wcześniejszych rozważań są one zdaniem Skarzyńskiego ,wręcz niedorzeczne”. W drugiej edycji Der Begriff des Politischen Schmitt zmienił koncepcję państwa totalnego, którą krytykował, w koncepcję normatywną, tym samym dając „narzędzie legitymizacji narodowosocjalistycznej dyktatury" ${ }^{59}$. Dlaczego jednak tak się stało? Według Skarzyńskiego Schmitt, podobnie jak inni prawicowi intelektualiści Republiki Weimarskiej, nie rozumiał istoty powstającego systemu, „błądził, nieudolnie wykorzystując stworzoną przez siebie teorię do wspomożenia własnej kariery"60.

Schmitt był początkowo normatywistą, jednak porzucił normatywizm dla decyzjonizmu, którego z kolei wyrzekł się w 1934 roku $^{61}$. Nigdy nie rozwinął swojej koncepcji na tyle, aby — jak twierdzi Skarzyński — wykluczyć wszelkie domysły i konieczność dookreślania podstawowych założeń. Obok Hermanna Hellera Schmitt był uczonym, który rozpoznał kryzys niemieckiej teorii państwa. Obaj położyli podstawy pod samookreślenie się politologii, ale z uwagi
56 Ibidem, s. 21.
57 Ibidem, s. 22.
58 Ibidem, s. 23.
59 Ibidem, s. 25.
60 Ibidem, s. 27.
61 Ibidem, s. 27-29. 
na sprzeczności Schmitta to Heller wyemancypował politologię jako odrębną od nauk prawnych ${ }^{62}$.

Cztery wersje Der Begriff des Politischen nie są według Skarzyńskiego jedynie ciekawostką, lecz „dowodem wątpliwości rozdzierających Schmittowskie ujęcie problemu tego, co polityczne, ugruntowane jego nie do końca uświadomionymi konsekwencjami kryzysu normatywizmu i teorii państwa"63. Lektura porównawcza kolejnych edycji prowadzi Skarzyńskiego do wniosku, iż filozofię polityczną Schmitta można interpretować na dwa, znajdujące uzasadnienie $\mathrm{w}$ tekstach, sposoby. W pierwszej interpretacji decyzjonizm jest prowojenny, wychwalający przemoc i państwo totalitarne - we wszechogarniającym konflikcie uczestnicy dążą do unicestwienia wroga i zachowania swojego istnienia; interpretacja ta występuje w Der Begriff des Politischen z 1933 roku. W drugiej („obiektywnej, realistycznej”) wersji — z lat 1927, 1932 i 1964 — uczestnicy konfliktu w sytuacji wyjątkowej stoją przed możliwością walki, wynikającą z niemożliwości rozstrzygnięcia konfliktu przez stronę trzecią ${ }^{64}$. Takie interpretacje są możliwe, twierdzi Skarzyński, gdyż sam Schmitt określał swoje idee w sposób abstrakcyjny, tym samym narażający go na krytykę. W pracach „wolnych od prohitlerowskiego zaangażowania” widoczna jest druga, „realistyczna” wersja. „Schmitt nie głosił w nich haseł nawołujących do wojny, nigdy nie postulował dyskryminacji wroga, starał się jedynie - pisze Skarzyński - dociec, na czym polega polityczność ludzkiej egzystencji i jakie konsekwencje wypływają z jej specyfiki" 65 . Odczytywanie tej wersji decyzjonizmu przez liberalne okulary nie ma jednak nic wspólnego ze Schmittem ${ }^{66}$.

Koncepcję decyzjonizmu zrodziło wiele procesów: kryzys normatywizmu i niemieckiej Staatslehre, upadek wytyczających życie społeczne idei, rozpad wartości i sekularyzacja pojęć politycznych ${ }^{67}$. Skarzyński podkreśla odrębność Schmitta od tradycji kontrrewolucyjnej, który — inaczej niż klasycy konserwatyzmu (nawet mu współcześni) — nie dążył do obrony wartości absolutnych, nie szukał metafizycznej podstawy monarchii, lecz przedkładał zmaganie się $\mathrm{z}$ aktualną sytuacją nad zwrot ku przeszłości ${ }^{68}$. Wychodząc z diagnozy kryzysu dotychczasowych form legitymizacji (suweren do państwa jak Bóg do świata), przedstawił krytykę demokracji parlamentarnej i liberalizmu ${ }^{69}$.

62 Ibidem, s. 31-33.

63 Ibidem, s. 34.

64 Ibidem, s. 38-39.

65 Ibidem, s. 40.

66 Ibidem, s. 39-40. Według Skarzyńskiego w literaturze dotyczącej Schmitta istnieją trzy podstawowe dezinterpretacje koncepcji tego, co polityczne: (1) koncepcja tego, co polityczne jest prowojenna; (2) teoria Freund-Feind uzasadnia politykę ukierunkowaną na zniszczenie wroga;

(3) Schmitt zajmował się pojęciem polityki, a nie tego, co polityczne. Zob. ibidem, s. 40-41.

67 Ibidem, s. 53-54.

68 Ibidem, s. 54, 58; por. R. Skarzyński, Carl Schmitt — ideolog i politolog..., s. 46.

69 Ibidem, s. 55-57. 
Antropologiczna koncepcja Schmitta wynika z uznania człowieka za złego z natury, którą to interpretację narzuca forma państwa. Demokracja nie może się opierać na założeniu, że człowiek jest z natury zły, a dyktatura — odwrotnie, iż jest z natury dobry. Jak stwierdza Skarzyński, interesy polityczne „wyprzedzają powstanie szerszej perspektywy filozoficznej"70. Refleksja Schmitta nad naturą człowieka nie jest zdaniem politologa szczególnie rozbudowana, a więc wymaga rekonstrukcji. Decyzjonizm w ujęciu teoriopolitycznym jest „pozornie” umocowany $\mathrm{w}$ antropologii, ponieważ istotniejsza jest sytuacja egzystencjalna rozstrzygającą o tym, co polityczne ${ }^{71}$.

Koncepcja stanu natury Schmitta jest podobna do Hobbesowskiej. Obaj zdaniem Skarzyńskiego chcieli wykazać konieczność „regulacji pierwotnych form konfliktu” (stan natury), z którego ma nastąpić przejście do „cywilizacji” (stanu państwowego $)^{72}$. Stan natury i stan państwowy są różnymi stanami politycznymi pierwszy to walka między grupami (Schmitt) lub jednostkami (Hobbes) w sytuacji braku suwerena, podczas gdy drugi cechuje obecność suwerena, który określa to, co polityczne. Dla obu myślicieli „drogą do cywilizacji jest droga polityczna”, w której suweren wyprowadza rzeczywistość $\mathrm{z}$ chaosu ${ }^{73}$. Filozofia polityczna Schmitta opiera się na suwerenie tworzącym na wzór Boga ład państwowy z chaosu stanu natury ${ }^{74}$. Suweren ma monopol na polityczność, dlatego pluralizm samodzielnie określających swą polityczność (według rozróżnienia przyjaciela i wroga) grup jest przynależny jedynie stanowi natury ${ }^{75}$. Niepaństwowy aktor na poziomie państwa może natomiast wystąpić przeciw władzy państwowej w stanie wojny domowej ${ }^{76}$. Stąd właśnie wynika nastawienie decyzjonizmu na stan wyjątkowy związany z zagrożeniem państwa ${ }^{77}$. Państwo nie musi jednak być jedynym podmiotem politycznym w koncepcji Schmitta, mogą istnieć grupy polityczne w obszarze państwa, ale celem państwa jest ich likwidacja. Prowadzona przez suwerena polityka zdaniem Skarzyńskiego sprowadza się więc do „działań prewencyjnych, zabezpieczających przed skrystalizowaniem się jakiejkolwiek podmiotowości politycznej”" ${ }^{78}$. Dlatego najlepsza w okiełznaniu wewnętrznych zagrożeń jest dyktatura, w której suweren jest strażnikiem ładu ${ }^{79}$. Pisząc o stanie wyjątkowym, będącym fazą pośrednią między stanem normalnym a stanem natury, Schmitt polemizował z pozytywizmem prawniczym, żeby pokazać, iż decyzja suwerena o stanie wyjątkowym nie podlega

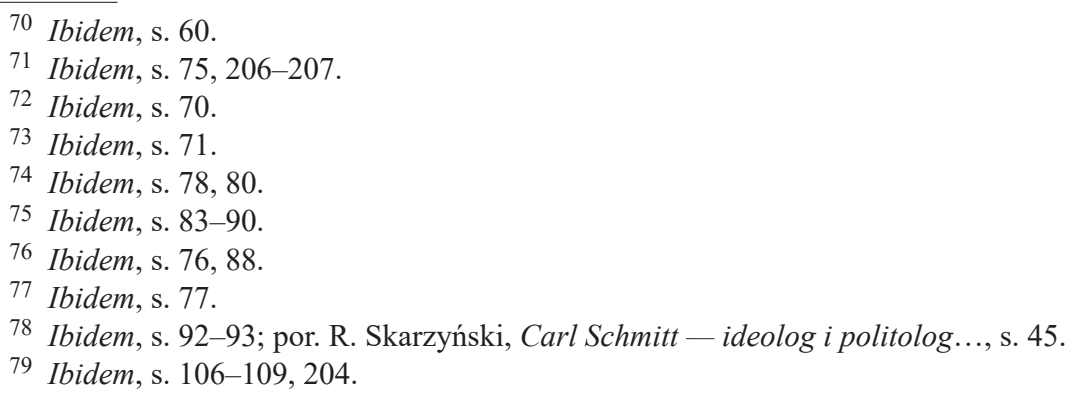


żadnym unormowaniom ${ }^{80}$. Podobnie skrajne stanowisko, zdaniem Skarzyńskiego, zajął Schmitt wobec kwestii przetrwania podmiotów politycznych, których egzystencja nie wymaga według niemieckiego teoretyka jakiegokolwiek uzasadnienia ${ }^{81}$.

Według Skarzyńskiego Schmitt w kolejnych edycjach Der Begriff des Politischen przyjął nie tylko różne koncepcje państwa i decyzjonizmu, lecz także pojęcia tego, co polityczne. W pierwszym wydaniu z 1927 roku oznaczało ono odrębny obszar ludzkiej aktywności, w drugim zaś, z 1932 roku, „relację pomiędzy autonomicznymi podmiotami, cechującą się swoistą intensywnością, wynikającą z faktu, czy pozostają one wobec siebie w stosunku przyjaźni, czy też wrogości" ${ }^{\prime 2}$. Zdaniem Skarzyńskiego ważniejsze jest jednak to drugie ujęcie, ponieważ sam Schmitt wycofał się z wcześniejszych propozycji ${ }^{83}$.

Niemiecki teoretyk nie rozróżnił precyzyjnie między tym, co polityczne, a polityką, ale wykazał znaczenie problemu ,tego, co polityczne” w refleksji nad polityką, albowiem, jak pisze Skarzyński, nie mając koncepcji tego, co polityczne, nie wiemy, na czym polega „polityczność polityki”"84. W ogóle refleksja Schmitta dotycząca pojęcia polityki jest ograniczona, gdyż oddając ją w domenę suwerena, ograniczył jej zasięg do sfery relacji międzypaństwowych ${ }^{85}$.

Podsumowując, należy skonstatować, że Od chaosu do tadu... jest najbardziej całościowym polskim opracowaniem koncepcji polityczności Schmitta. W interpretacji Skarzyńskiego Schmitt nie jest konserwatystą odwołującym się do metafizycznych uzasadnień idei politycznych, lecz piewcą nadrzędności historycznej sytuacji, która determinuje widzenie świata i działanie ${ }^{86}$. Schmitt w jego ujęciu uznaje historyczność egzystencji człowieka również w dziedzinie wartości, akceptując zmiany polityczne i nieuchronną sekularyzację ${ }^{87}$. Doktryna decyzjonizmu jest więc konserwatywną odpowiedzią na kryzys polityczny Republiki Weimarskiej.

„Antysocjologizm” (rozumiany jako niezdolność do głębszego wniknięcia w naturę zjawisk) Schmitta, który miał „mętne wyobrażenie o strukturze społecznej i interesach grupowych, a nawet [wobec nich] wstręt", stanowi główny zarzut Skarzyńskiego, piszącego z pozycji metodologii socjologii weberowskiej. Właśnie wiara w „mityczną całość” społeczeństwa sprowadziła Schmitta na „manowce”, czyniąc go rzecznikiem dyktatury ${ }^{88}$. Postulat dyktatury był ,produktem marzeń o stabilnym

80 Ibidem, s. 99-102.

81 Ibidem, s. 115.

82 Ibidem, s. 131-141.

83 Ibidem, s. 142.

84 Ibidem, s. 167-173, 206. Skarzyński, powołując się na Webera, twierdzi, że brak refleksji nad naturą tego, co polityczne, źródłem i istotą polityki prowadzi do mówienia o ,polityce kulturalnej” czy „polityce mieszkaniowej”, czyli sprowadza politykę do działalności zarządczej. Zob. ibidem, s. 172.

85 Ibidem, s. 173-184.

86 Ibidem, s. 60; por. R. Skarzyński, Carl Schmitt - ideolog i politolog..., s. 43, 48.

87 Ibidem, s. 61.

88 Ibidem, s. 92, 112, 204. 
ładzie państwowym", a zatem — w świetle socjologii — decyzjonizm był nieuzasadniony, ,ideologiczny”. Przyczyna takiego stanu rzeczy zdaniem Skarzyńskiego leży w tym, że Schmitt był prawnikiem, więc ,zadowalała go [...] analiza nazbyt formalna, badanie prostych zależności pomiędzy takimi kategoriami, jak ład polityczny i ład normatywny, rozumianymi przez niego dość schematycznie, wręcz w uproszczony sposób, jeśli weźmie się pod uwagę możliwości dociekań socjologicznych" 89 . Sformułowany przez niego decyzjonizm był jednak teorią polityczną $\mathrm{i}$,mocno osadzoną w tradycji konserwatywnej filozofią polityczną wypowiadającą się przeciwko pluralistycznemu państwu, podmiotowości grup społecznych, demokracji i negocjacji jako metodzie kształtowania woli politycznej narodu" 90 .

\section{4.}

W równym stopniu konstytutywną dla omawianego ujęcia interpretację przedstawił związany wówczas ze Szkołą Główną Handlową, a obecnie Uniwersytetem Kardynała Stefana Wyszyńskiego filozof, znawca teorii państwa, Paweł Kaczorowski. Jego główną pracą, a zarazem drugą polską monografią dotyczącą filozofii politycznej Carla Schmitta jest książka My i oni: państwo jako jedność polityczna. Filozofia polityczna Carla Schmitta $w$ okresie republiki weimarskiej ${ }^{91}$. Warszawskiego badacza Schmitt interesuje jako „,myśliciel wydobywający filozoficzną treść z pojęć prawnych, ale nie jako po prostu filozof albo krytyk modernistycznej kultury"92.

Od wcześniejszych ujęć Ryszki i Skarzyńskiego interpretację Kaczorowskiego różni ostrożne podejście do idei Schmitta. O ile jego poprzednicy mieli ambicje być weberystami w ocenie Niemca, co widać w tym, że odróżniali myśl od dzieła, poglądy od praktyki, unikając w ten sposób wartościowania, jednoznacznego potępienia, o tyle Kaczorowski nie kontynuuje tego sposobu myślenia. Poglądy Schmitta są jego zdaniem „niebezpiecznie jednostronne”, ale stanowią ważny element nie tylko wiedzy politycznej, ale też ,teorii demokratycznego państwa". Postulat badawczy Kaczorowskiego zamyka się w zdaniu dotyczącym idei niemieckiego teoretyka:

89 Ibidem, s. 204. Skarzyński uważa, że ustalenia Schmitta byłyby „bardziej dogłębne i przekonywające”, gdyby uwzględnił analizę struktury grupowej społeczeństwa, występujących interesów i zależności wynikających z więzi gospodarczych i kulturowych.

90 Ibidem, s. 203; por. R. Skarzyński, Konserwatyzm: zarys dziejów filozofii politycznej, Warszawa 1998.

91 P. Kaczorowski, My i oni: państwo jako jedność polityczna. Filozofia polityczna Carla Schmitta $w$ okresie republiki weimarskiej, Warszawa 1998. Praca Kaczorowskiego jest dobrym wprowadzeniem ogólnym do myśli Carla Schmitta, gdyż omawia niemal wszystkie główne problemy jego filozofii politycznej. Szczególną zaletą monografii jest duża ilość i objętość (nierzadko pełna strona) cytowanych fragmentów dzieł Schmitta (i innych myślicieli), co miało i ma znaczenie w sytuacji niedostępności wszystkich tekstów po polsku.

92 Ibidem, s. 92. 
trzeba je uważać za materiał do rozważań, a nie za źródło bezpośredniej wiedzy. Trzeba więc ich raczej... zażywać, ostrożnie, po namyśle i we właściwych proporcjach, bo są jak trucizna, trucizna, która czasami leczy, ale tylko wtedy, gdy jest używana w bardzo małych dawkach ${ }^{93}$.

Kaczorowski, jak sam twierdzi, pragnie wykazać sens poglądów Schmitta, a nie rozstrzygać o ich prawdziwości ${ }^{94}$.

Podobnie jak wcześniej Ryszka autor My i oni wyróżnia dwa rodzaje myślenia politycznego: normatywno-racjonalistyczny (Locke, Rousseau) i empiryczno-historyczny (Hobbes, Machiavelli), na których podstawie mogą istnieć dwie koncepcje życia społecznego — odpowiednio, koncepcja wspólnoty (prawa naturalnego) lub władzy absolutnej ${ }^{95}$. Oba sposoby myślenia politycznego nie mówią jednak nic o rzeczywistości, dlatego potrzebna jest filozofia polityczna oparta na „wiedzy konkretnej i szczegółowej, jaką niesie zobiektywizowane doświadczenie jednostkowe, pamięć zbiorowa i nauki społeczne, prawne, historyczne", a nie filozofia polityczna, ,zamknięta w obrębie czystych pojęć i postulowanych przez nią samą ideałów" ". Nowością ujęcia Kaczorowskiego jest założenie, że Schmitt nie wpisuje się wprost $\mathrm{w}$ żadną $\mathrm{z}$ tych filozofii politycznych. Jego zdaniem myślenie Schmitta, łączące empiryczne i filozoficzne nastawienie, jest czymś pośrednim, wykraczającym poza zarysowaną opozycję, nie stanowi zatem kontynuacji tradycyjnej systemowej refleksji politycznej ${ }^{97}$.

Poglądy Schmitta Kaczorowski umieszcza na tle rozwoju niemieckiej teorii państwa i debat z Hellerem i Kelsenem. Główna różnica między nimi polega na tym, że Kelsen i Heller zakładali wtórność polityki w stosunku do państwa, dla Schmitta zaś to polityka była pierwotna wobec państwa ${ }^{98}$. Jednak zdaniem Kaczorowskiego „nazbyt ścisłe traktowanie” teorii Schmitta jako odpowiedzi na dyskusję o jedności porządku państwowego ,zniekształci jej treść"99. Według warszawskiego politologa stałaby się ona wówczas teorią problemu czysto teoretycznego, abstrakcyjnego, a więc niezwiązanego z codziennym życiem politycznym.

„Polityka ${ }^{100}$ — rekonstruuje pogląd Schmitta Kaczorowski — jest wszędzie tam, gdzie dochodzi do przeciwstawienia my i oni" ${ }^{101}$. Zdaniem badacza polityka w ujęciu niemieckiego myśliciela ma charakter totalny, odnosi się do każdej

\footnotetext{
93 Ibidem, s. 18.

94 Ibidem, s. 241.

95 Ibidem, s. $7-10$

96 Ibidem, s. 15.

97 Ibidem, s. 17.

98 Ibidem, s. 32-42.

99 Ibidem, s. 22-33.
}

100 Kaczorowski, acz niekonsekwentnie, pisze o „polityce”, a nie, zależnie od polskiego tłumaczenia niemieckiego das Politische, o „tym, co polityczne” (według Skarzyńskiego) lub „polityczności" (propozycja Cichockiego).

101 Ibidem, s. 50. Rozróżnienie Freund-Feind Kaczorowski proponuje zastąpić „,powszechnie znaną opozycją” my i oni, ponieważ sojusznik-wróg ,po polsku niewiele znaczy”, a gdy mówi się o przeciwstawieniu my i oni, od razu wiadomo, że chodzi o politykę. 
dziedziny ludzkiej aktywności. Polityka rozumiana jest przez Schmitta zarazem jako pierwotna i wtórna wobec państwa, ,jako gra sił politycznych" w sytuacji przedpaństwowej oraz działanie państwa ${ }^{102}$. Według Kaczorowskiego ,ilekroć zaczynamy myśleć coś o innych w zależności od tego, czy postrzegamy ich jako naszych wrogów, czy sprzymierzeńców, to - choćby w sposób nieświadomy, nie wyartykułowany — zaczynamy już myśleć politycznie"103. Słowo das Politische, które Schmitt wybrał dla odróżnienia tego, co polityczne, jako „sfery wyznaczonej przez charakter aktywności" od polityki rozumianej jako konkretne działania, jest określeniem polemicznym, ponieważ stanowi krytykę dominującego wówczas pojęcia polityki jako odrębnej sfery działań ${ }^{104}$.

Spojrzenie Schmitta na wynikający z natury ludzkiej antagonizm polityczny jest podobne do opisu stanu natury według Hobbesa. Według Kaczorowskiego można uznawać obu za pokrewnych sobie intelektualnie, gdyż Schmitt był autorem rozprawy na temat Lewiatana ${ }^{105}$. Ważniejsza jednak jest różnica między nimi - Hobbes pisze o relacjach między jednostkami, a Schmitt o relacjach między grupami. Opis Hobbesa jest przedstawieniem „,rzekomej natury ludzkiej”, stwierdza Kaczorowski, Schmitt zaś opisuje rzeczywistość ${ }^{106}$. Przedstawiona przez Schmitta koncepcja polityczności jest „opisem historycznego faktu” pozbawionym wartościowania, ponieważ interesuje go to, co jest, jaka jest polityka, a nie jaką być powinna ${ }^{107}$.

Co interesujące, poglądów Schmitta, zdaniem Kaczorowskiego, nie da się ze względu na znaczące różnice zakwalifikować do nurtu filozofii politycznej, którego przedstawicielami są Bodin, Machiavelli czy Hobbes ${ }^{108}$. U Hobbesa, którego warszawski badacz przyjmuje za reprezentatywnego dla wspomnianej grupy, polityka jest „świadomym, racjonalnym działaniem wyjątkowej jednostki, która wbrew ludzkiej naturze nie jest dla innych »wilkiem«, lecz kieruje się ku [...] wartościom [...], jak pokój i bezpieczeństwo", natomiast u Schmitta polityka jest dążeniem motywowanego interesem własnym podmiotu zbiorowego do stworzenia porządku społecznego ${ }^{109}$. Schmitt, inaczej niż Hobbes czy Donoso Cortès, nie dąży do wyjaśnienia istoty natury ludzkiej, ponieważ w jego teorii podmiotem polityki są nie jednostki, lecz grupy ${ }^{110}$.

Osobowy aspekt decyzji o stanie wyjątkowym w koncepcji Schmitta wpisuje się zdaniem Kaczorowskiego w dwie — filozoficzną i prawną — tradycje myślowe.

\footnotetext{
102 Ibidem, s. 48.

103 Ibidem, s. 50.

104 Ibidem, s. 70.

105 Ibidem, s. 53.

106 Ibidem, s. 54.

107 Ibidem, s. 65.

108 Ibidem, s. 77

109 Ibidem, s. 78.

${ }^{110}$ Ibidem, s. 86-87.
} 
Pierwsza z nich to irracjonalizm pascalowski (zakład Pascala), podkreślający rolę decyzji i wyboru w życiu; stanowi on przeciwieństwo racjonalizmu oczekującego znalezienia rozwiązania na zasadnicze pytania (o istotę bytu, los, dobro, śmierć) i odpowiedź na upadek wiary w tę siłę rozumu. Schmitta, jak Kierkegaarda, charakteryzuje pogląd, iż świat jest „,chaotyczny, sprzeczny, nieunormowany, nieprzewidywalny", dlatego niemożliwe jest racjonalne poznanie świata. Wspólne dla Schmitta i irracjonalizmu jest również przekonanie o „kryzysowym charakterze współczesności, kultury europejskiej XIX i XX wieku"111.

Drugi nurt, w który wpisuje się refleksja Schmitta, to dziewiętnastowieczny nurt rozważań nad rolą pojęć nieostrych w prawie (na przykład bezpieczeństwo, dobro społeczne, porządek publiczny). Do takich pojęć, których nieostrość zwiększa możliwość swobodnego uznania odpowiednich władz, można zdaniem Kaczorowskiego zaliczyć Schmittowskie pojęcie stanu wyjątkowego. Jednakowoż istnieje znacząca różnica między decyzją w prawie administracyjnym a decyzją o sytuacji wyjątkowej. Tę różnicę Kaczorowski podkreśla, pisząc o pierwotności specyficznego zjawiska w stosunku do pojęcia prawnego ${ }^{112}$.

Według Kaczorowskiego Schmitt nie jest „zdeklarowanym decyzjonistą”, lecz zwolennikiem porządku konkretnego (niem. konkretes Ordnungsdenken), dla którego opozycja prawa naturalnego i dyktatu władzy jest fałszywa ${ }^{113}$. Można interpretować jego poglądy jako decyzjonistyczne, ale „całościowy sens jego teorii jest inny"114. Tym sensem jest to, że integrujący społeczeństwo porządek w ramach państwa jedności politycznej tworzy suweren reprezentujący najsilniejszą zbiorowość.

W ujęciu Kaczorowskiego Schmitt jest nie tylko teoretykiem polityki (wewnętrznej i międzynarodowej) w sensie ogólnym, ale też w sensie szczegółowym — krytykiem liberalizmu, parlamentaryzmu i egalitarnej demokracji ${ }^{115}$. Teologia polityczna niemieckiego myśliciela to politologiczna teoria sekularyzacji powiązana z koncepcją dziedzin centralnych w danej epoce historycznej ${ }^{116}$. Koncepcje Schmitta nie mają metafizycznego charakteru, nie są również idealnym projektem porządku politycznego, lecz opisem rzeczywistości historyczno-politycznej XIX-XX wieku ${ }^{117}$.

Rozważania prawnicze, szczególnie teoria konstytucji Schmitta, nie są w ujęciu Kaczorowskiego rozumiane w sposób przedstawiony w wyróżnionej przez nas interpretacji Schmitta jako prawnika-konstytucjonalisty ${ }^{118}$, lecz jako teoretyka
111 Ibidem, s. 90-92.
112 Ibidem, s. 93-95.
113 Ibidem, s. 112.
114 Ibidem, s. 135-136.
115 Ibidem, s. 175-198.
116 Ibidem, s. 139-154.
117 Ibidem, s. 223-240.
118 Por. Ł. Święcicki, Carl Schmitt w polskich interpretacjach... 
polityki. Kaczorowski (za Böckenfördem) uznaje, iż Naukę o konstytucji należy rozumieć przez pryzmat Pojęcia polityczności, ponieważ negowana przez liberalizm polityczność pozostaje nie bez wpływu na porządek życia zbiorowego ${ }^{119}$. Teoria Schmitta jest z gruntu realistyczna, twierdzi Kaczorowski, dlatego liberalizm ignorujący realia nie znajduje jego uznania. Nie przeszkadza to jednak autorowi My $i$ oni podjąć próby wpisania koncepcji Schmitta w teorię demokratycznego państwa ${ }^{120}$. Według Kaczorowskiego Schmitt jest zwolennikiem demokracji jako „formy sprawowania władzy”, którą zgodnie z prawami historii wyrażającymi się w postępującej od XIX wieku demokratyzacji uznaje za fakt, którego „nie można ignorować, jeśli chce się o porządku państwa myśleć realnie, a nie w sposób oderwany od rzeczywistości”"121.

\section{Schmitt jako konserwatysta}

Konserwatyzm Schmitta dostrzegany był w tekstach wcześniejszych, zarówno w okresie tak zwanej Polski Ludowej, jak i później w pracach politologicznych (vide wspomniany Skarzyński). Interpretacje te traktowały jednak konserwatyzm Schmitta jako pozbawiony odniesień metafizycznych i transcendentalnych. W opozycji do takiego stanowiska rozwinęły się na gruncie politologicznym interpretacje Marka Cichockiego oraz Adama Wielomskiego.

\section{1.}

W swojej monografii Ciagtość i zmiana. Czy konserwatyzm może nie być rewolucyjny? Cichocki dużo miejsca poświęcił Carlowi Schmittowi, którego określił mianem wizjonera, ale i oportunisty ${ }^{122}$. Można powiedzieć, iż wiele też od niego przejął, zwłaszcza krytyczną ocenę romantyków politycznych, a także niektóre pojęcia (complexio oppositorum) i koncepcje (na przykład decyzjonizmu jako postawy konserwatysty).

Schmitt, ,niespokojny, pełen pomysłów erudyta, o niewątpliwej wiedzy filozoficznej", jest dla Cichockiego przede wszystkim filozofem politycznym, dlatego nazistowski epizod z lat 1933-1936 zdaniem warszawskiego badacza nie powinien wpływać na rozumienie koncepcji autora Der Begriff des Politischen ${ }^{123}$. Niemiecki filozof kierował się głównie motywami prawnymi w swym działaniu,

119 P. Kaczorowski, op. cit., s. 208.

120 Ibidem, s. 241-249.

121 Ibidem, s. 222-223.

122 M. Cichocki, Ciagłość i zmiana. Czy konserwatyzm może nie być rewolucyjny?, Warszawa 1999.

${ }^{123}$ Ibidem, s. 178-179. 
więc mimo niechęci do Republiki Weimarskiej chciał bronić państwa przed pozaprawnymi działaniami nazistów.

Przystąpiwszy do NSDAP dopiero po uchwaleniu Ermächtigungsgesetz, zauważa Cichocki, podzielił los innych niemieckich intelektualistów dwuznacznie nastawionych do Hitlera, który atakował skutecznie Weimar, ale ciągnął za sobą szerokie masy, wobec których należałoby jako konserwatyście zachować odpowiedni dystans ${ }^{124}$. Akces do nowego reżimu traktuje więc Cichocki jako postawę oportunistyczną, która Schmittowi się nie opłaciła, gdyż stał się obiektem szykan narodowosocjalistycznego reżimu, a potem wykluczenia w powojennych Niem$\operatorname{czech}^{125}$.

Myśl Schmitta jest w ujęciu autora Ciagłości i zmiany... antytradycjonalistyczna, piętnująca retorykę „postępu wstecznego”, estetyzowanie rzeczywistości i pasywność, a także antyliberalna ${ }^{126}$. Liberalizm Schmitt krytykuje $\mathrm{z}$ uwagi na indywidualizm i jego konsekwencje. Według Schmitta, jak rekonstruuje ów pogląd Cichocki, liberalizm „dokonuje [...] zabiegu sprywatyzowania i politycznego zneutralizowania osoby"127. Na gruncie tej prywatyzacji i neutralizacji osoby do jednostki mogły powstać pozytywizm prawniczy i teoria społeczeństwa obywatelskiego, które Niemiec krytykuje.

Jednak liberalizm, zdaniem Cichockiego, nie jest największym „wrogiem” Schmitta, który dostrzegł bezproduktywność w tworzeniu przeciwieństwa liberalizm-tradycjonalizm. „Odrzucając relację tradycjonalizm-liberalizm Schmitt pragnie — pisze Cichocki - przenieść punkt ciężkości na płaszczyznę egzystencjalną", które to przeniesienie ma odsłonić zapomniany sens ludzkiej egzystencji i jej tragiczny wymiar ${ }^{128}$. Tym wymiarem, a zarazem istotą polityczności, jest rozróżnienie między przyjacielem a wrogiem, które pewne koncepcje (Cichocki nie pisze wprost o liberalizmie) próbują zignorować jako ,przejaw barbarzyństwa" lub znieść przez edukację, prawo czy mediację ${ }^{129}$. Tymczasem to rozróżnienie poprzez wydobycie ludzi z obojętności, izolacji, bezpieczeństwa prywatnych nisz ukazuje sens istnienia ${ }^{130}$. Konserwatyzm Schmitta jest w takim ujęciu „filozoficznym fundamentalizmem” rozumianym jako chęć przywrócenia „filozoficznych i religijnych źródeł kultury i cywilizacji” dla odzyskania sensu ludzkiej egzystencji ${ }^{131}$.

Obrona sensu w świecie go pozbawionym jest według Cichockiego głównym przesłaniem myśli Schmitta. $Z$ tego względu zasadniczym przedmiotem

\footnotetext{
124 Ibidem, s. 174-177.

125 Ibidem, s. 176-178.

126 Ibidem, s. 180-181.

127 Ibidem, s. 181.

128 Ibidem, s. 183.

129 Ibidem, s. 186.

130 Ibidem, s. 187-188.

131 Ibidem, s. 184.
} 
krytyki niemieckiego filozofa jest „ekonomiczne myślenie” ludzi podzielonych na konsumentów i producentów. Powaga i dramatyzm losu w takim świecie zostają zastąpione przez zabawę i poczucie bezpieczeństwa. Zdaniem Cichockiego Schmittowska krytyka takiego stanu rzeczy ma swoje religijne źródła i ujawnia przewagę, jaką Niemiec daje wierze nad rozumem. Świat opisany i krytykowany przez Schmitta jest więc obelgą wobec Boga ${ }^{132}$. Człowiek pozostawiony sam wobec „własnych sił sprawczych [...] bez wahania zniszczy wszystkie formy w imię wątpliwej absolutnej wolności twórczej”, dlatego konieczny człowiekowi do zbawienia jest autorytet ${ }^{133}$.

Decyzjonizm Schmitta Cichocki łączy z krytyką rozumowania przyczynowego Hume'a, według którego reguł moralnych nie można uzasadnić przyczynowo. Hegla z kolei, zdaniem warszawskiego badacza, Schmitt traktował instrumentalnie, odrzucając heglowską dialektykę, albowiem katolicyzmowi dialektyka jest obca, podobnie zresztą jak dualizm materii i formy ${ }^{134}$. Poszukując innej racjonalności w Kościele katolickim, Schmitt sprzeciwia się alternatywie zarysowanej przez postkantystów (w tym Kelsena) - racjonalne reguły prawa pozytywnego albo nieograniczona przemoc autokraty ${ }^{135}$. Odpowiedzią jest autorytet wyrażający jedność osoby i instytucji, reprezentujący Boga lub ideę na ziemi, który, niczym papież, łączy w sobie różne role (kapłana, pasterza, Kościoła, hermeneuty doktrynalnego, sędziego) ${ }^{136}$.

Kreśląc całościowy obraz świata i człowieka organizowany przez polityczność, Schmitt, zdaniem Cichockiego, odrzuca opozycje naturalny-sztuczny, rozumnyinstynktowny, racjonalny-irracjonalny. Zamiast racjonalistycznego i tradycjonalistycznego dualizmu Schmitt proponuje postawę afirmacyjną — duchowość, która zostaje przeciwstawiona liberalnej wizji kultury współczesnej ${ }^{137}$.

Wydaje się, że autorytet w koncepcji Schmitta, twierdzi Cichocki, może reprezentować jakąkolwiek ideę, albowiem tylko reprezentując ideę, można w ogóle toczyć spór polityczny. „Nie do przyjęcia jest taki porządek społeczny, w którym nie ma za co umierać, [a] jest to przypadek współczesnego, konsumerskiego społeczeństwa" - stara się oddać pogląd Schmitta Cichocki. Według autora Ciagłości $i$ zmiany... Schmitt uważa, iż świat (każdej) idei jest prawdziwszy od świata „na poziomie wyboru między różnymi proszkami do prania”, nawet jeśli ideę reprezentuje szalony dyktator ${ }^{138}$.

\footnotetext{
132 Ibidem, s. 188-189.

133 Ibidem, s. 219, 228.

134 Ibidem, s. 198-205.

135 Ibidem, s. 210.

136 Ibidem, s. 212-213.

137 Ibidem, s. 211.

138 Ibidem, s. 216-217.
} 
W interpretacji Marka Cichockiego Carl Schmitt zestawiony z Jacobem Burckhardtem i Friedrichem Nietzschem jest filozofem politycznym broniącym rzeczywistości przed nihilizmem, w który jednak sam popada.

Myślą Schmitta jako konserwatysty zajmował się również Adam Wielomski. Znany głównie z badań nad francuską i hiszpańską myślą polityczną politolog swój pierwszy tekst dotyczący Schmitta poświęcił nieprzypadkowo jego recepcji we frankistowskiej Hiszpanii ${ }^{139}$. Dowiadujemy się z niego, że myśl Schmitta pojawiła się w Hiszpanii w drugiej połowie lat trzydziestych, czyli wtedy, jak pisze Wielomski, gdy Schmitt ,zaparł się swoich zasadniczych poglądów, aby móc wyrazić poparcie dla systemu hitlerowskiego" ${ }^{140}$. Co więcej, stała się ona przedmiotem zainteresowania nie komentatorów i historyków myśli politycznej, lecz pełnokrwistych filozofów i prawników, takich jak między innymi Alvaro d'Ors czy Francisco J. Conde. W Hiszpanii Schmitt był czytany — zresztą w przekładach, których było sporo - jako ten, który przedstawił rozróżnienie na konstytucję stanowiącą zbiór podstawowych dla danego narodu zasad, praw i tradycji prawnych, ustrojowych i świadomościowych oraz prawo konstytucyjne rozumiane jako zbiór paragrafów, w jaki ujęto zasady konstytucji. Jak pisze Wielomski, opozycja ta interesowała Hiszpanów, ponieważ pozwalała postawić pytanie o prawowitość obalenia reżimu, czyli złamania obowiązującego porządku konstytucyjnego. Rozumowano w ten sposób, że skoro najpierw jest ład, a potem przepisy konstytucji, to „nie należy się wahać”141. Hiszpańscy teoretycy uznawali, że zagrażające porządkowi ruchy wywrotowe (komuniści, socjaliści, anarchiści) wykorzystują prawo konstytucyjne do unicestwienia ,prawdziwej” konstytucji narodu. Generał Franco - „klasyczny decyzjonistyczny dyktator” - jest więc obrońcą konstytucji, który staje ponad literą prawa w celu zachowania jego ducha (ładu) ${ }^{142}$.

Koncepcje Schmitta spotkały się w Hiszpanii również z krytyką: faszyzująco-falangistowską i konserwatywno-karlistowską. W pierwszym ujęciu zarzucano Schmittowi niezrozumienie istoty demoliberalnego państwa, w którym nie należy, jak proponował niemiecki profesor prawa, depolityzować społeczeństwa, lecz wpływać przez propagandę i interwencjonizm państwa na masy ${ }^{143}$. W drugim uważano, że właściwym wrogiem Hiszpanii jest wróg zewnętrzny — ateistyczna

139 A. Wielomski, Carl Schmitt we frankistowskiej Hiszpanii, „Pro Fide, Rege et Lege” 1998, nr 3-4; por. idem, Decyzjonizm: recepcja Carla Schmitta w Hiszpanii, [w:] idem, Hiszpania Franco. Źródta i istota doktryny politycznej, Biała Podlaska 2006.

140 A. Wielomski, Carl Schmitt we frankistowskiej Hiszpanii..., s. 16.

141 Ibidem, s. 14, 16.

142 Ibidem, s. 15.

143 Ibidem, s. 16. 
i demoliberalna Europa ${ }^{144}$. Zarzucano Schmittowi odrzucenie prawa naturalnego, a przez to niezrozumienie natury konserwatywnej wizji ładu, brak podstaw metafizycznych i aksjologicznych. Dlatego, jak pisze Wielomski, postanowiono „uchrystianizować” decyzjonizm, aby bronił jedynie „prawdziwego” porządku opartego na tradycji i prawie naturalnym w katolickim rozumieniu ${ }^{145}$. Hiszpańscy prawnicy powrócili więc do przypomnianego im przez Schmitta Donoso Cortèsa. Zdaniem Wielomskiego przykładem zastosowania koncepcji dyktatury komisarycznej w praktyce są rządy Franco jako tymczasowego zastępcy monarchy, który po opanowaniu nastrojów rewolucyjnych wróci na swój tron ${ }^{146}$.

To ujęcie Carla Schmitta jako myśliciela odwołującego się do filozofii katolickich tradycjonalistów de Maistre'a i Donoso Cortèsa Wielomski rozwiną w książce Konserwatyzm. Główne idee, nurty i postacie z 2007 roku $^{147}$. Schmitt jest tu twórcą doktryny politycznej decyzjonizmu, najwybitniejszym prawnikiem krytykującym demokrację i konserwatystą, który przeszedł, jak pisze Wielomski za Arminem Mohlerem, „oś czasu”" ${ }^{148}$. Skłonność wyrosłego w tradycji katolicyzmu Schmitta do autorytaryzmu wynika według badacza ze zlaicyzowanej idei ultramontańskiej władzy papieża nad Kościołem ${ }^{149}$.

Teoria Schmitta kształtuje się zdaniem Wielomskiego w latach 1928-1933 — w okresie, w którym zbliżył się do konserwatywnej i nacjonalistycznej prawi$\mathrm{cy}^{150}$. Rozrywana konfliktem wewnętrznym, walkami partyjnymi, zagrożona rewolucją z prawa i lewa republika potrzebowała autorytetu, który zaprowadzi ład i porządek, dlatego gdy pojawili się naziści, ,przerażony” ich prymitywizmem Schmitt „buduje [...] koncepcję uzasadniającą możliwość rozwiązania przez prezydenta parlamentu i delegalizacji dominujących partii skrajnych: komunistów i nazistów", którą zawarł w Verfassungslehre oraz Der Hüter der Verfassung ${ }^{151}$.

Według Wielomskiego koncepcja ta nie jest doktryną polityczną, lecz interpretacją „teoretycznie nic nieznaczącego” art. 48 ust. 2 konstytucji. To jednak z interpretacji tego właśnie artykułu powstają ,idee filozofii prawa” tworzące „teorię państwa autorytarnego" Carla Schmitta: powierzenie prezydentowi dbałości o porządek publiczny, prawo do wydawania przez prezydenta rozporządzeń z mocą ustawy, decyzjonistyczny charakter prezydentury (prezydent poza prawem wprowadza stan wyjątkowy) oraz idea dyktatury prezydenta ${ }^{152}$.

\footnotetext{
144 Ibidem, s. 17.

145 Ibidem.

146 Ibidem, s. 17-18.

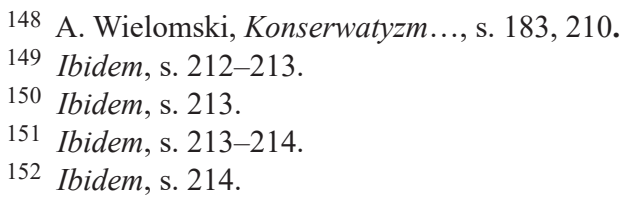

147 A. Wielomski, Konserwatyzm. Gtówne idee, nurty i postacie, Warszawa 2007, s. 183-221; por. idem, Aksjologiczne fundamenty dyktatury u Carla Schmitta, „Pro Fide, Rege et Lege” 2005, nr 2-3. 
Istotą decyzjonizmu Schmitta jest „kontrrewolucyjna dyktatura, kryjąca się za pozorami obrony Weimaru", gdyż ewentualny zamach prezydenta Paula von Hindenburga byłby narodzinami nowej Rzeszy, cesarstwa bez cesarza pod maską dotychczasowego stanu ${ }^{153}$. Legitymizacja władzy suwerena wynika nie z porządku konstytucyjnego, lecz z naśladowania Boga czyniącego cuda, którego ziemskim odpowiednikiem jest suweren ${ }^{154}$.

Schmitt był zdaniem Wielomskiego politycznym realistą w sensie makiawelicznym, uznawał więc, że polityka jest z natury niemoralna, a wartości i idee służą jedynie interesom grup ${ }^{155}$. Decyzjonizm stawia zatem politykę ponad systemami aksjologicznymi w celu ratowania ładu. Właśnie stosunek do wartości odróżnia dyktaturę od monarchii - monarchia w przeciwieństwie do dyktatury odwołuje się do wartości religijnych. „Schmitt — pisze Wielomski — postulował dyktaturę i opierał jej prawowitość na naśladownictwie Boga, ale nie głosząc przy tym idei, iż ma ona restaurować religijne zasady"156. W obliczu nierzeczywistości konserwatysta „traci wiarę we wszelkie wartości”, dlatego „zostaje mu tylko bezideowa dyktatura dla utrzymania jakiegokolwiek ładu” i „,wołanie o wodza” 157 .

Zarysowane interpretacje Schmitta jako konserwatysty są preludium do ujęcia jego myśli w perspektywie teologii politycznej lub, inaczej, problemu teologiczno-politycznego. Swoje rozwinięcie znalazły w późniejszych studiach, które należy jednak zaliczyć do nowego nurtu badań polskich nad myślą Schmitta ${ }^{158}$.

$* * *$

Podsumowując, należy stwierdzić, że polską recepcję politologiczną Schmitta $\mathrm{w}$ omawianym okresie zdominowały dwa podejścia. $\mathrm{W}$ jednym niemieckiemu filozofowi przyglądano się z perspektywy teorii polityki, a więc konkretnych problemów i kategorii politologicznych dostrzeganych w myśli Niemca. W drugim ujęciu badania prowadzono w kontekście konserwatyzmu, starając się wykazać nowatorski charakter myśli Schmitta jako tego, który odrzuca lub twórczo rozwija klasyków tej doktryny. Oba proponowane w artykule podejścia mają w oczywisty sposób charakter teoretyczny. Z łatwością można dostrzec punkty styczne występujące $w$ interpretacjach badaczy. Podobieństwa dotyczą przede wszystkim zerwania z moralizatorstwem w ocenie postawy Schmitta oraz chęci wykazania istotnego wkładu Niemca czy to do teorii polityki, czy to do konserwatyzmu. Z pewnością badania Pawła Kaczorowskiego są przypadkiem szczególnym, niewpisującym się idealnie w zaproponowane w artykule kategorie. Sam autor jest

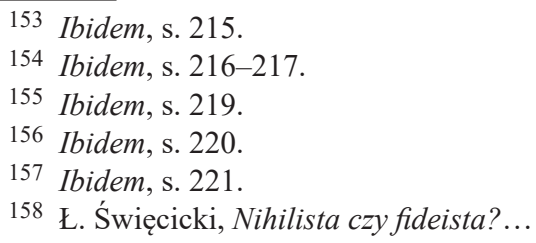

153 Ibidem, s. 215.

154 Ibidem, s. 216-217.

155 Ibidem, s. 219.

156 Ibidem, s. 220.

157 Ibidem, s. 221.

158 Ł. Święcicki, Nihilista czy fideista?... 
filozofem z wykształcenia, wykładowcą na wydziale politologii, znawcą teorii państwa i prawa, który nie wiąże swoich naukowych zainteresowań z typową uniwersytecką teorią polityki. Jego badania zaś nie dają się zakwalifikować jako przynależne wprost do historii doktryn politycznych typowej dla prawników. Poglądy Schmitta Kaczorowski wprawdzie umieszcza na tle rozwoju niemieckiej teorii państwa, historycznie je kontekstualizując, zarazem jednak uniwersalizuje je w typowy dla filozofii polityki sposób. Ponieważ autor My i oni oprócz analiz myśli Schmitta przedstawia własne rozważania z zakresu teorii państwa, należy zaliczyć go do pierwszego wyróżnionego przeze mnie nurtu badań, czyli „Schmitt jako teoretyk polityki”. W tym względzie Kaczorowski, podobnie jak wcześniej Skarzyński, twórczo interpretuje myśl Niemca.

Prezentowanych badaczy różni nie tylko podejście metodologiczne, to, czy prowadzą swoje rozważania z perspektywy teorii polityki, czy historii myśli politycznej, ale w jeszcze większym stopniu - sposób odczytania znaczenia transcendencji w myśli Carla Schmitta. Wszyscy interpretatorzy dostrzegają „realizm” jego myśli, jednak różnie go rozumieją. Zauważają fakt odrzucenia odniesień metafizycznych w koncepcji Niemca, lecz inaczej go wyjaśniają, widząc przyczynę już to w samym Schmitcie, już to w niemożliwości uzasadnienia takich odniesień w zeświecczonym świecie. Zewnętrzne przyczyny nieobecności „wartości” w doktrynie Schmitta stanowią problem dla oceny tego myśliciela jako konserwatysty. Staje się on w ten sposób myślicielem nietypowym dla reprezentowanej tradycji, który restauruje doktryny tradycjonalistyczne i na sposób zsekularyzowany przetwarza je dla nowej sytuacji.

Podsumowując, stwierdzam, że w pierwszym przypadku (Franciszek Ryszka, Ryszard Skarzyński, Paweł Kaczorowski) Schmitt jest badany z perspektywy teorii polityki i teorii państwa, a więc analizowane są poszczególne kategorie teoretyczne rozwijane przez autora Pojęcia polityczności. Najwięcej uwagi badacze poświęcają koncepcji polityczności Schmitta jako ważnej propozycji teoretycznej na gruncie politologicznym. W drugim wypadku (Marek Cichocki, Adam Wielomski) Schmitt widziany jest jako przedstawiciel pewnego nurtu ideowego, to jest doktryny konserwatyzmu. W ujęciu Schmitta jako teoretyka polityki badacze analizują jego myśl w całości, rozkładając ją na czynniki pierwsze, nie rozstrzygając o jego ideologicznej przynależności. Z kolei w ujęciu Schmitta jako konserwatysty myśl Niemca jest dla badaczy ważna jako myśl konserwatywna i przez pryzmat przynależności do tego nurtu myśli politycznej rozpatruje się poszczególne koncepcje autora Pojęcia polityczności. 


\section{Bibliografia}

Baldus M., Carl Schmitt im Hexagon: Zur Schmitt-Rezeption in Frankreich, „Der Staat” 26, 1987, nr 4.

Baszkiewicz J., Ryszka F., Historia doktryn politycznych i prawnych, Warszawa 1973.

Benoist A. de, Carl Schmitt: Internationale Bibliographie der Primär- und Sekundärliteratur, Graz 2010.

Chacon V., Die Rezeption Carl Schmitts in Brasilien, „Schmittiana. Beiträge zu Leben und Werk Carl Schmitts", t. 5, Berlin 1996.

Cichocki M., Ciagłość i zmiana. Czy konserwatyzm może nie być rewolucyjny?, Warszawa 1999.

Kaczorowski P., My i oni: państwo jako jedność polityczna. Filozofia polityczna Carla Schmitta w okresie republiki weimarskiej, Warszawa 1998.

Mauss I., Bürgerliche Rechtstheorie und Faschismus. Zur sozialen Funktion und aktuellen Wirkung der Theorie Carl Schmitts, München 1980.

Meier H., Die Lehre Carl Schmitts. Vier Kapital zur Unterscheidung Politischer Theologie und Politischer Philosophie, Stuttgart-Weimar 2009.

Mouffe Ch., The Return of the Political, London-New York 1993.

Polskojęzyczna bibliografia Carla Schmitta (do 2012 r.), oprac. Ł. Święcicki, „Pro Fide Rege et Lege" 2014-2015, nr 1.

Ryszka F., Carl Schmitt w nauce prawa i polityki XX w. Twórca i jego dzieło. Szkic do portretu $i$ wybrane watki teorii, „Studia nad Faszyzmem i Zbrodniami Hitlerowskimi” 19, 1996.

Ryszka F., Nauka o polityce. Rozważania metodologiczne, Warszawa 1984.

Ryszka F., O pojęciu polityki, Warszawa 1992.

Ryszka F., Polityka i wojna. Świadomość potoczna a teorie XX wieku, Warszawa 1975.

Skarzyński R., Carl Schmitt - ideolog i politolog, [w:] Carl Schmitt i współczesna myśl polityczna, red. R. Skarzyński, Warszawa 1996.

Skarzyński R., Carl Schmitt i współczesny konserwatyzm europejski, „Archiwum Historii Myśli Politycznej" 1991, nr 1.

Skarzyński R., Konserwatyzm: zarys dziejów filozofii politycznej, Warszawa 1998.

Skarzyński R., Od chaosu do ładu: Carl Schmitt i problem tego, co polityczne, Warszawa 1992, 2012.

Skarzyński R., Teoria polityki w okresie przełomu: Carl Schmitt i problem tego, co polityczne, „Państwo i Kultura Polityczna” 1991, nr 3.

Skarzyński R., Wróg i sojusznik. Studium struktury myśli politycznej, „Studia Nauk Politycznych” 1990, nr 1-3.

Święcicki Ł., Carl Schmitt w polskich interpretacjach prawniczych (1928-2008), „Studia nad Autorytaryzmem i Totalitaryzmem" $36,2014, \mathrm{nr} 4$.

Święcicki Ł., Nihilista czy fideista? O polskim sporze wokót Carla Schmitta, „Pro Fide Rege et Lege" 2017, nr 1-2.

Święcicki Ł., O recepcji Carla Schmitta w Polsce, „Pro Fide Rege et Lege” 2017, nr 1-2.

Wielomski A., Aksjologiczne fundamenty dyktatury u Carla Schmitta, „Pro Fide, Rege et Lege” 2005, nr 2-3.

Wielomski A., Carl Schmitt we frankistowskiej Hiszpanii, „Pro Fide, Rege et Lege” 1998, nr 3-4.

Wielomski A., Decyzjonizm: recepcja Carla Schmitta w Hiszpanii, [w:] idem, Hiszpania Franco. Źródta i istota doktryny politycznej, Biała Podlaska 2006.

Wielomski A., Interpretacje Carla Schmitta na świecie i w Polsce, ,Studia nad Faszyzmem i Zbrodniami Hitlerowskimi” 33, 2011.

Wielomski A., Konserwatyzm. Główne idee, nurty i postacie, Warszawa 2007.

Wielomski A., Konserwatyzm między Atenami a Jerozolima: szkice post-awerroistyczne, Warszawa 2009.

Studia nad Autorytaryzmem i Totalitaryzmem 41, nr 4, 2019

(C) for this edition by CNS 


\section{Summary}

The article discusses Polish political-science interpretations of the German legal and political theorist Carl Schmitt. It gives an overview of the main literature published between the 1980s and 2000s. Polish political scientists became interested in Schmitt only after a period of intensive studies conducted by lawyers. Polish political science, ideologically oriented during the times of the communist regime, took its leading role in Schmitt's reception with the transformation of Poland's political system. Interestingly, the flow of new translations of Schmitt's writings in the first decades of the century shifted the reception substantially and moved it towards more philosophical and theological interpretations. The interpretations present in the field of political science have been divided into two kinds based on different methodologies: the first, focused on Schmitt as a political theorist, which aims at introducing his substantial contributions to political science, and the second, which focuses on Schmitt as a representative of conservatism. The article may serve as a practical introduction to Polish political-science research on Schmitt.

Keywords: Carl Schmitt, political science, reception, Poland, interpretations, political thought.

Łukasz Święcicki

lukasz.swiecicki@uph.edu.pl 